Intersections

Canadian Journal of Music

Revue canadienne de musique
Intersections

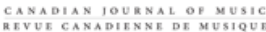

\title{
A Portrait of Composer Steven Gellman for His Seventieth Birthday
}

\section{Roxane Prevost}

Volume 36, numéro 2, 2016

URI : https://id.erudit.org/iderudit/1051595ar

DOI : https://doi.org/10.7202/1051595ar

Aller au sommaire du numéro

Éditeur(s)

Canadian University Music Society / Société de musique des universités canadiennes

ISSN

1911-0146 (imprimé)

1918-512X (numérique)

Découvrir la revue

Citer cet article

Prevost, R. (2016). A Portrait of Composer Steven Gellman for His Seventieth Birthday. Intersections, 36(2), 27-34. https://doi.org/10.7202/1051595ar
Résumé de l'article

Cet article consiste en une courte biographie du compositeur canadien Steven Gellman, suivie d'un échange avec lui, à l'occasion de son soixante-dixième anniversaire en 2017. La biographie souligne son parcours allant d'un jeune garçon intéressé par la composition jusqu’à ses études avec Messiaen et sa carrière canadienne. Notre conversation avec le compositeur repose sur une série de quatorze questions qui lui ont été soumises au sujet de son processus créatif et ses réflexions sur sa carrière de compositeur.
Copyright (c) Canadian University Music Society / Société de musique des universités canadiennes, 2018
Ce document est protégé par la loi sur le droit d'auteur. L'utilisation des services d'Érudit (y compris la reproduction) est assujettie à sa politique d'utilisation que vous pouvez consulter en ligne.

https://apropos.erudit.org/fr/usagers/politique-dutilisation/ 


\section{A PORTRAIT OF COMPOSER STEVEN GELLMAN FOR HIS SEVENTIETH BIRTHDAY ${ }^{1}$}

\section{Roxane Prevost}

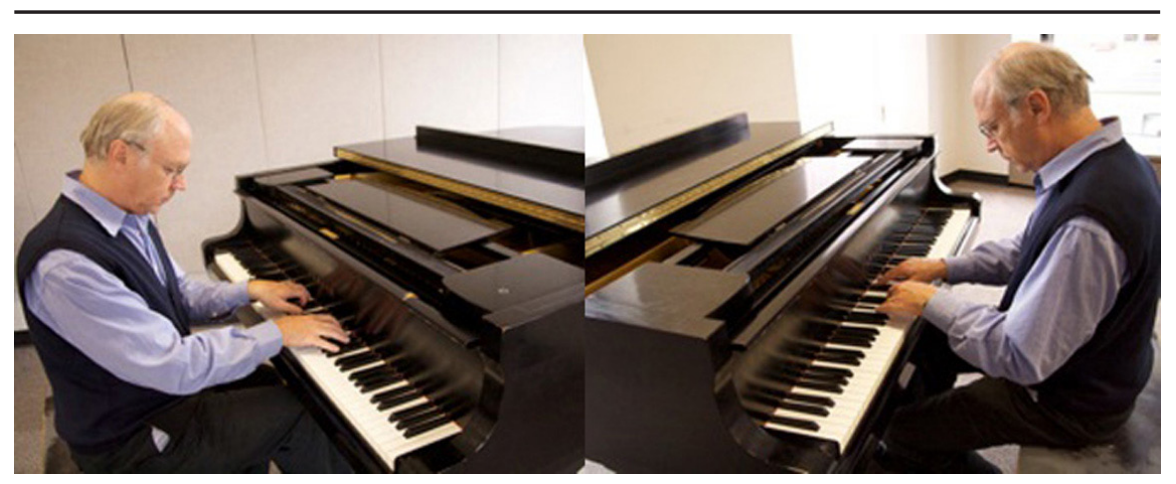

Steven Gellman, 2010. Photo by James Law, used by permission.

\section{INTRODUCTION}

Professor Steven Gellman, born in Toronto in 1947, began composing at the age of nine, followed two years later by studies in theory, composition, and piano at the Royal Conservatory of Music with Samuel Dolin. As part of the opening ceremonies for the University of Toronto's Edward Johnson Building in 1964, he performed his Concerto for Piano and Orchestra with the CBC Symphony Orchestra under Boyd Neel at the age of sixteen and received an international BMI Award to Young Composers, the first awarded to a Canadian, that same year. Gellman then embarked on studies at the Juilliard School of Music (19658) with world-leading composers Luciano Berio, Vincent Persichetti, and Roger Sessions. In the summers (1965-6), he studied with Darius Milhaud at the Aspen Music Festival School in Colorado, where he won first prize for composition (1966). His return to Toronto in 1968 allowed him time to study electronic music with Dolin. In 1970 he received the UNESCO prize for "Best Work by a Composer under the Age of 25" for Mythos for flute and string quartet. With bursaries from the Canada Council for the Arts, he continued his composition studies under the tutelage of Olivier Messiaen at the Conservatoire de Paris

1 Biographical information extracted from Steven Gellman's website (http://www.steven gellman.com/) and correspondence with the author. 
(1973-6), where he won a Premier Prix in analysis (1975) and a Premier Prix in composition (1976). His Chori, an extensive work for large orchestra, was premiered by the Toronto Symphony Orchestra in 1975. The following year, he began teaching composition at the University of Ottawa. In 1978 the French government commissioned Gellman to compose Deux Tapisseries to celebrate Olivier Messiaen's seventieth birthday; the work for fifteen players was performed by the Ars Nova Ensemble, under the direction of Marius Constant, at the Festival de Besancon (France) on 11 September 1978 and was reprised in Paris one month later. In the late 1970s he composed works such as Wind Music commissioned by the Canadian Brass, and Poème for pianist Angela Hewitt.

Gellman was commissioned by the Toronto Symphony Orchestra to write Awakening (1983), which was premiered in the TSO's first season in Roy Thompson Hall and performed while the orchestra was on tour in Europe in 1983. His Universe Symphony (1986), also commissioned by the TSO through grants from

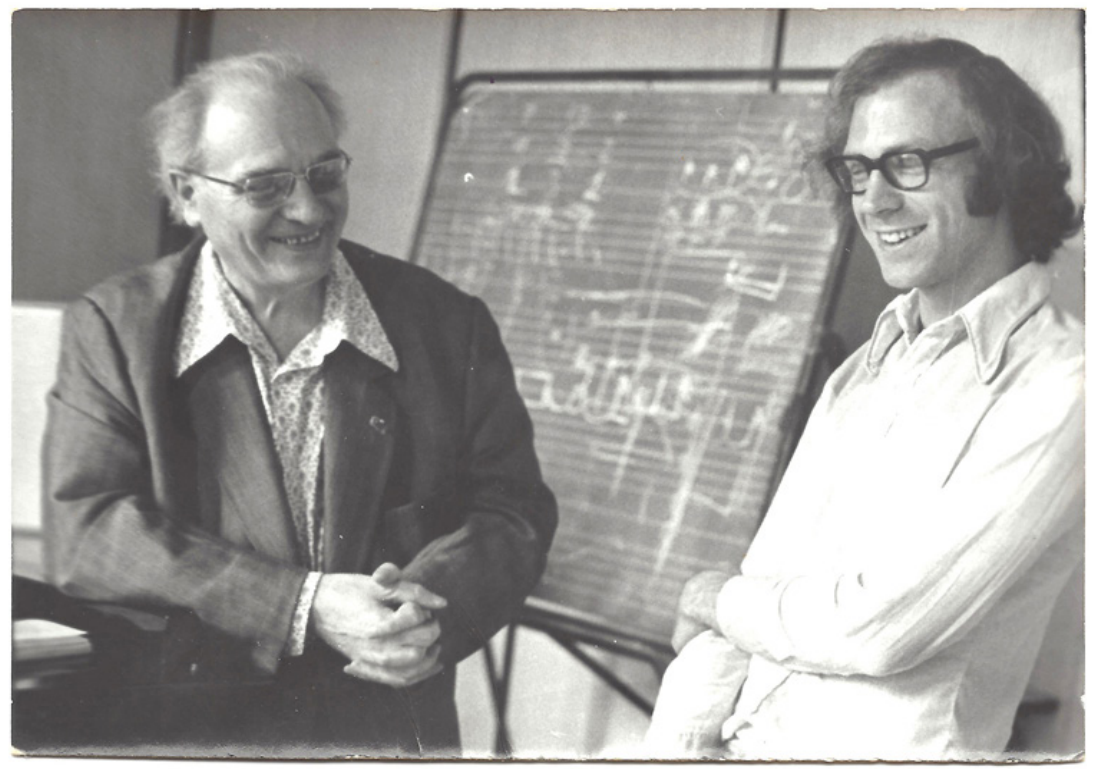

Olivier Messiaen and Steven Gellman, 1975, used by permission.

the Canada Council for the Arts and the Ontario Council for the Arts, was premiered with the orchestra and synthesizers from the Canadian Electronic Ensemble, under the baton of Andrew Davis. The work was also performed at Expo 86 in Vancouver with the Vancouver Symphony Orchestra, the Orchestre Métropolitain de Montréal at the Festival de Lanaudière, and the Ottawa Symphony Orchestra in Ottawa.

Gellman was named "Composer of the Year" by the Canadian Music Council in 1987, and the Syrinx Concert Series in Toronto featured him as composer in 2005-6 by including his works in a series of concerts. The Ottawa Symphony Orchestra, under the direction of David Currie, premiered his Viola 
Concerto featuring Jethro Marks, principal violist with the National Arts Centre Orchestra, in 2007. His Musings was premiered by the Gryphon Trio at the Ottawa Chamber Music Festival in 2009. His music was also featured at the Prince Edward County Music Festival (2010), as well as the Agassiz Festival in Winnipeg (2010). Throughout his career as a composer his works have been performed by many of Canada's most acclaimed groups, and he has been commissioned to write works by numerous organizations, including the $\mathrm{CBC}$, the Stratford Music Festival, the Toronto Symphony Orchestra, the National Arts Centre Orchestra, the Hamilton Philharmonic, the Canadian Brass, the Manitoba Chamber Orchestra, Radio Canada, Musica Camerata, and individuals, such Angela Hewitt, who commissioned his Fantasia on a Theme of Schumann for her New York and London debuts in 1984, and Jon Kimura Parker, who commissioned Keyboard Triptych for Piano/Synthesizer (1986) for his tour in Canada, the United States, and Britain.

One characteristic of Gellman's music lies with its wide appeal to audiences of different backgrounds. He lists his musical influences as eclectic and encompassing repertoire from the eighteenth- to twenty-first-century classical tradition, jazz music, and, as his spouse Cheryl would point out, the Beatles. $\mathrm{He}$ defines his harmonic language as a "mixture of ... diatonic with added notes ... modal, and free chromatic, and often the free chromatic is grounded with something tonal at the same time." This description brings to the forefront the main appeal of his music: he captivates the listener by including elements that will be somewhat familiar, but at the same time he intrigues the listener by bringing something new. The melding of different styles and techniques also contributes to the freshness, yet familiarity, of his works and gives him his unique compositional voice.

Throughout his career as a university professor, Gellman has guided many young composition students, and most students would agree that his sense of humour makes his classes that much more interesting. In a class presentation a

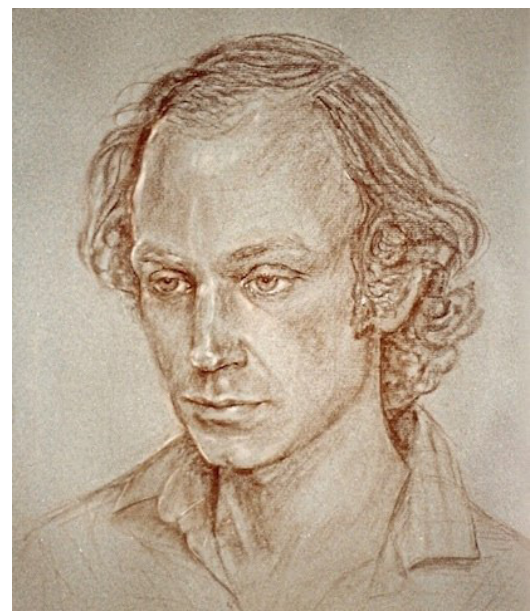

Portrait of the artist as a young Man, 1982. Cheryl Gellman, used by permission. 
few years ago, after explaining that he first perceives musical material, such as chords and themes, internally and then replays it on the piano, a student asked if he had ever forgotten the material before he had a chance to "find it on the piano." Gellman replied, "I'll tell you about the ones that got away!" He retired from the University of Ottawa in 2011 as emeritus professor but continues to remain active as a composer.

\section{CONVERSATION With THE COMposer}

In a recent exchange, I asked Gellman for his perspective on a wide range of issues.

Prevost. How did you begin composing? When did you first realize that this was something that you wanted to do?

Gellman. I first started composing at the age of nine. I had been studying the piano for about a year, and at the end-of-year recital I played my little set pieces by Bach, Mozart, and Schubert. Shortly afterwards a boy slightly older than I played his set pieces, followed by his own original piece for piano. That moment was a revelation for me: "You can do this too?" That summer I filled a notebook with little piano pieces and songs and continued composing throughout my next year of piano study. By the end of that year I had dozens more pieces, some larger-like sonatinas for piano and violin, as well as the beginning of a symphony (this was written as a piano score with my intended instrumentation pencilled above the notes-I had not yet seen an orchestral score). At the end of my second year my piano teacher took me to the best composition teacher in Toronto, Dr. Samuel Dolin, who accepted me as a student in composition and piano. Over the next few years he gave me an excellent foundation in all of my music theory subjects: harmony, counterpoint, orchestration, analysis, etc., as well many opportunities to compose and perform my early works in public. He would also hire professional musicians to perform his students' original works in public, and I benefited greatly from those occasions.

Prevost. Who are your main influences? What kinds of music do you listen to? What are your inspirations?

Gellman. My main influences have evolved over the years. When I began to compose, my favourite composers were Beethoven, Mozart, and Bach, soon joined by Schumann, Brahms, and Prokofiev. As a young teenager I discovered the Moderns, and my favourite composer was Bartók. Later in my teens I added Debussy, Mahler, Berg, and Shostakovitch. By my early twenties I was studying Berio, Messiaen, and Ligeti, amongst others. At the same time, growing up in the late sixties, I discovered and participated in the great "Rock Renaissance" of that era. My early piece, "Odyssey" for rock group and orchestra, reflected that musical exploration. I also love music by Sibelius, Bruckner, Mahler, and Messiaen, to name a few.

Prevost. How do you compose? Do you sit at the piano? Do you sketch out ideas on paper?

Gellman. In my early years I was really a pianist/composer and most often would improvise on the piano and retain and develop the best ideas for my 
compositions. As I matured the inspiration became gradually more internal, especially during my twenties when I was travelling through many different countries, often without access to a piano. Now I compose mostly on the inner plane, making sketches of my ideas and using the piano only to verify my harmonies, which are original and particular to my own musical style.

Prevost. How would you describe your musical style? Would you classify your works into periods or styles?

Gellman. I really do not like labels, which I find generally too limiting. However, I guess you could say that essentially I am a modern-romantic composer. My musical style has undergone several main changes in my life. My earliest period, as a student teenager, was modelled after my favourite composers at that time. In my twenties my explorations became more experimental and modern: characteristic works from that period being Mythos, Chori, Sonate pour Sept, and Animus-Anima. A new period was ushered in with Trikāya, in which I was stripping away all unessential modernistic-complicated tendencies and aiming for a more essential musical expression. This period culminated with Universe Symphony and included my (second) Piano Concerto (the first was composed when I was fourteen and premiered with me as soloist with the CBC Symphony), Love's Garden for Soprano and Orchestra, the Canticles of Saint Francis of Assisi for Choir and Orchestra, and Musica Eterna, amongst others. My more recent works include my Piano Quartet, Viola Concerto, Madrigal, Musings for Piano Trio, as well as a collaborative work with a modern dance company-an "opera-ballet"-The Dybbuk.

PREVOST. Your recent works incorporate many altered traditional chords (major, minor, seventh). Is this tied to your studies with Messiaen and/or the music to which you listen?

Gellman. My musical language, especially harmonic, has evolved a lot through the years. I was introduced to serial (twelve-tone) language early in my teens. This was during the "modernist period" where tonality was frowned upon! However, by nature I am drawn to tonal centres, so it is no mystery that I was attracted then to the music of Bartók, whose style was decidedly modern but always maintained strong tonal centring. Later when I was studying with Messiaen in Paris, I continued to evolve my harmonic language under his influence (he was a master of musical colour) and even incorporated some of his symmetrical modes into my music. At the same time, I was striving to build my own musical language, absorbing some of his influence but maintaining my own style. For example, much of my Piano Concerto (1988) is composed using Messiaen's "second mode of limited transposition," but the music does not at all sound like Messiaen. I had to make it my own in order to employ it.

Prevost. Do you have a preference for specific genres or combinations of instruments?

Gellman. My favourite "instrument" is the orchestra. It offers the composer an almost unlimited spectrum of combinations of sound colours with the greatest range of volume and densities. Also in scoring more complex textures built on polyphony, the orchestra enables a clearer separation of the voices and the pleasant challenge of colouring each of them effectively. Being a young 
pianist/composer, my earliest music was mostly for piano, but once I graduated through chamber combinations and into the large range of the orchestra, that became my major fascination as a composer.

Prevost. You have recently worked with a dance/theatre group. Is multimedia something that interests you for future projects? Are there challenges or benefits in collaborating with other artists? Is this something that you would like to continue to explore?

GeLlman. Fairly recently I was commissioned by a modern dance company in Calgary to collaborate with them to produce an opera-ballet. The dancers were very highly skilled in dance; however; their principal-and-choreographer wanted them to sing as well. My challenge was to help train them vocally and to compose the music that they would be able to sing while dancing. It was a very enjoyable experience for all the participants, who were able to expand their artistic capabilities, and it came off quite successfully. I enjoyed the collaboration with other creative artists and would welcome exploring further multimedia projects.

Prevost. How do you choose titles for your works?

Gellman. Titles do not come easily to me. Most of my music is not descriptive by nature, and therefore descriptive titles do not often suit. Occasionally my wife, Cheryl, who is a gifted visual artist, listens to my thoughts about the piece I am creating and comes up with the best title. A good example of this is when I was describing to her a vast symphonic "space-scape" in five movements that I was drafting under the heading "Symphonic Meditations." She listened to me, and after a pause said, "You should call it Universe Symphony!" Another title from her visual art world was "Chiaroscuro."

PREvost. Are any of your works autobiographical?

Gellman. In general my works are not actually biographical, but some of them do include biographical elements. My early Second Symphony, for example, certainly expressed a young man's heroic aspirations, and it ends with a "Journey to the East," which reflected my own life at that time. More recently both my Piano Quartet and Viola Concerto contain some very sorrowful passages, which reflect family tragedies of that time in my life.

Prevost. Do you have a favourite piece that you have written?

Gellman. I do not have one favourite piece that I have written. Universe Symphony has been called my signature work by many people. It is one of my favourites, along with my Viola Concerto, Musica Eterna, Canticles of Saint Francis, Piano Concerto (1988), Piano Quartet, and Piano Trio "Musings," Burnt Offerings for String Orchestra, Trikāya, Jaya Overture, Keyboard Triptych for Piano/Synthesize, and the Mystic Symphonic Poem "The Bride's Reception."

Prevost. Are some of your compositional decisions affected by how an audience will perceive your work?

Gellman. In general, I do not compose my music for audiences. My works are the products of my own deep contemplation and aspire to the expression of "Truth and Beauty." (I did say I was a modern-romantic artist!) 
Prevost. Do you feel that contemporary music could reach wider audiences? Do venues play a role in this accessibility? With your new website, do you find that technology can have a role in exposing audiences to new music?

Gellman. Contemporary music could reach a wider audience for several reasons. The nature of today's music is going through a great transition now. There is a fusion occurring between what were considered to be "classical" traditions and many indigenous and folk traditions (including rock and pop and world music). Younger composers all over the world are creating music that is integrating this wide-ranging spectrum in their own way, and the result in many cases is proving to have great appeal to their audiences. Venues should also be expanding to bring this music to wider audiences, and this is also happening through the internet; many sites are featuring music and they are easily accessible to everyone. I have recently relaunched my own website [stevengellman.com], on which several of my chamber and orchestral works can be heard, and I will add more of my music periodically. I am hoping that people will get to know my music through this venue.

Prevost. What would you consider important moments in your career as a composer?

Gellman. At age twenty I was commissioned by the Stratford Music Festival. The result was Mythos (for flute and string quartet), which we premiered in a theatrical setting on the Shakespearean stage. This piece was submitted to the UNESCO International Music Festival, where it was awarded the prize for "the best piece by a composer under the age of 25 ."

In 1971 Boris Brott and the Hamilton Philharmonic had the rock group Tranquility Base in residence, and he asked me to compose a concerto-like piece for them and orchestra. I added a solo piano part so I could participate, and a great time was had by all. This work, "Odyssey," was reprised a few months later in Toronto. Because I was travelling through India at the time, the piano part was taken up by Walter Buczynski.

In the early 1980 os Andrew Davis commissioned me for a concert-opening piece for the Toronto Symphony's tour throughout Europe in 1983. The resulting Awakening was performed in many of the European capitals, and my wife and I had a wonderful time travelling to all these countries with the orchestra.

On the basis of this tour's success, Andrew Davis then commissioned me to compose my major work, Universe Symphony, for large orchestra and live electronic sound (the synthesizers of the Canadian Electronic Ensemble), and this work was premiered in 1986 at Roy Thomson Hall in Toronto. It went on to receive other performances at Expo 86 in Vancouver, in Ottawa at the NAC, at the Festival de Lanaudière in Quebec, and later again in Toronto, and more recently in Ottawa with an updated electronic version. This work was cited by the Canadian Music Council in awarding me the title "Composer of the Year" (1987).

The Canadian Red Cross commissioned me to compose a work for choir and orchestra to celebrate their centennial. The Canticles of Saint Francis of Assisi was premiered in Ottawa at the National Arts Centre in 1989. 
Also in Ottawa the Ottawa Symphony premiered my Piano Concerto with Christina Petrowska as soloist, and more recently my Viola Concerto with Jethro Marks on solo viola.

Prevost. What would be your ideal commission?

GeLlman. At this stage of my creative life I would welcome more collaborative multimedia projects.

Gellman's archives have been deposited with the University of Ottawa Archives, where he was a distinguished professor for thirty-five years. His scores and some recordings are available at the Canadian Music Centre (musiccentre. ca), and recordings of his music are available on his website (stevengellman. com). He resides in Ottawa with his spouse, Cheryl, a visual artist.

\title{
REFERENCES
}

Gellman, Steven. "Composer Showcase." Canadian Music Centre. https:// www.musiccentre.ca/node/37189/showcase.

. "Steven Gellman." stevengellman.com.

-E-mail messages to author. 19 July to 17 August 2017.

\begin{abstract}
This article begins with a short biography of and an exchange with Canadian composer Steven Gellman, who celebrated his seventieth birthday in 2017. The biography outlines his life trajectory from a young boy interested in composition to his studies with Messiaen to his career in Canada. The exchange with the composer consists of fourteen questions on Gellman's creative process and his reflections on his career as a composer.
\end{abstract}

\section{RÉSUMÉ}

Cet article consiste en une courte biographie du compositeur canadien Steven Gellman, suivie d'un échange avec lui, à l'occasion de son soixante-dixième anniversaire en 2017. La biographie souligne son parcours allant d'un jeune garçon intéressé par la composition jusqu'à ses études avec Messiaen et sa carrière canadienne. Notre conversation avec le compositeur repose sur une série de quatorze questions qui lui ont été soumises au sujet de son processus créatif et ses réflexions sur sa carrière de compositeur.

\section{BIOGRAPHY}

Roxane Prevost is associate professor at the University of Ottawa, where she teaches undergraduate and graduate music theory and analysis. Her research interests include post-tonal music, rhythmic theories, and the music of Canadian composers. She has published articles in Intersections, Ex tempore: The Journal of Music Theory Pedagogy, Musurgia, and Australasian Canadian Studies and has presented at conferences in Canada, the United States, and Europe. 